\title{
Physical activity and sexual function in middle-aged women
}

\author{
Patrícia Uchôa leitão Cabral ${ }^{1}$, Ana Carla Gomes Canário MD ${ }^{1}$, Maria Helena Constantino Spyrides ${ }^{1}$, Severina Alice da \\ Costa UchôA ${ }^{1}$, José Eleutério Júnior ${ }^{2}$, Paulo Cesar Giraldo ${ }^{3}$, Ana Katherine Gonçalves ${ }^{1}$
}

${ }^{1}$ Federal University of Rio Grande do Norte, Natal, RN, Brazil

${ }^{2}$ Federal University of Ceará, Fortaleza, CE, Brazil

${ }^{3}$ Federal University of Campinas, Campinas, SP, Brazil

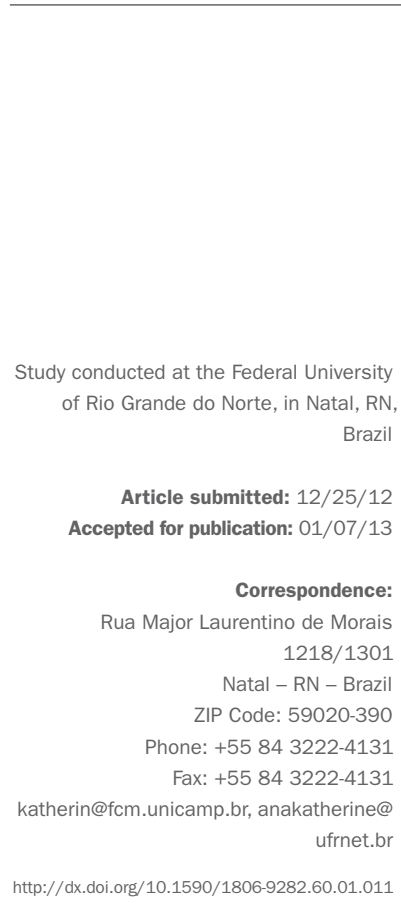

\section{SUMMARY}

Objective: To investigate the relationship between physical activity level and sexual function in middle-aged women.

Methods: A cross-sectional study with a sample of 370 middle-aged women (4065 years old), treated at public health care facilities in a Brazilian city. A questionnaire was used containing enquiries on sociodemographic, clinical and behavioral characteristics: the International Physical Activity Questionnaire (IPAQ), short form, and the Female Sexual Function Index (FSFI).

Results: The average age of the women studied was 49.8 years $( \pm 8.1), 67 \%$ of whom exhibited sexual dysfunction (FSFI $\leq 26.55)$. Sedentary women had a higher prevalence $(78.9 \%)$ of sexual dysfunction when compared to active $(57.6 \%)$ and moderately active $(66.7 \%)$ females $(p=0.002)$. Physically active women obtained higher score in all FSFI domains (desire, arousal, lubrication, orgasm, satisfaction and pain) and total FSFI score (20.9), indicating better sexual function than their moderately active (18.8) and sedentary (15.6) counterparts ( $\mathrm{p}<0.05)$.

Conclusion: Physical activity appears to influence sexual function positively in middle-aged women.

Key words: physical activity, sexuality, women, middle aged, menopause.

\section{INTRODUCTION}

Physical activity has long been known to maintain women's health and is frequently cited in the medical literature $^{1}$. Insufficient physical activity is also thought to be an important cause of obesity, diabetes, coronary heart disease and several types of cancer ${ }^{2,3,4}$.

Regular exercise improves physical fitness by increasing aerobic and musculoskeletal capacity ${ }^{1,5}$. This is directly related to better performance of daily tasks and seems to increase vigor, reduce fatigue and improve subjective well-being and quality of life by curbing disease ${ }^{1,6}$. Physical activity also has positive effects on depression symptoms and acts as an efficient antidepressant ${ }^{7}$. Moreover, the endocrine stress-regulation system can also be affected: athletes react better to stressful events ${ }^{8}$.

Evidence points to the fact that physical activity potentially invigorates people and changes mood positive${ }^{1 y}{ }^{9,10}$. Peluso \& Andrade ${ }^{10}$ also showed an association between physical activity and subjective well-being, while experimental studies support a positive effect on mood related to exercise of moderate intensity. The authors also claim that benefits are more probable if the individuals in question have personal improvement goals.

Studies have shown that feelings of satisfaction with life and well-being correlate with higher levels of sexual satisfaction and regular physical activity ${ }^{11-13}$; however, studies associating physical activity and sexual function are scarce. The only article studying perimenopausal Polish women showed a significant association between high levels of general physical activity and enhanced sexual function ${ }^{12}$.

However, physical activity declines with age and women are less active than men, particularly in leisure activities ${ }^{14}$. The female aging process promotes physical changes, in addition to emotional and social factors that may diminish their quality of life ${ }^{3}$. Menopausal symptoms were also less intense in women that exercised regularly ${ }^{15-18}$. Additionally, exercise has been shown to modify many menopausal symptoms, particularly mood, sleep, anxiety, depression, and musculoskeletal complaints ${ }^{15-17}$. Fewer psychosomatic 
symptoms and reports of sexual dysfunctions are observed in physically active menopausal women ${ }^{16}$.

Various reports seem to indicate a link between general quality of life, menopausal symptoms and sexual function in middle-aged women ${ }^{17-19}$. During menopause, a decrease in libido and sexual dysfunction occurs ${ }^{18-20}$. Moreover, sleep disorders, depressed mood and other psychological problems that reduce quality of life have a significant impact on female sexual function ${ }^{17,21}$.

In a longitudinal analysis, Elavsky et al. ${ }^{13}$ found that middle-aged women perceive their body more positively when physical activity levels are high, increasing their selfesteem, and maintaining a healthy Body Mass Index (BMI). Physical self-worth was found to have mental wellbeing properties when associated with measures of emotional adjustment ${ }^{22}$. There is solid evidence that exercise can change physical self-perception and identity in a positive way, ${ }^{5,10,13}$.

Although a large number of studies report the impact of physical activity on many aspects of women's health, very few address the relationship between physical activity and sexual function in middle-aged women.

The present study aims to assess the relationship between physical activity levels and sexual function in middle-aged women.

\section{Methods}

A cross-sectional study was performed from May to October, 2011, involving women from Natal, Brazil, treated at public health care facilities. Data collection was carried out in the four districts of the city (North, South, East and West). The sample consisted of women enrolled in the Family Health Program - Brazil's main primary health care strategy, which seeks to provide a full range of quality health care to families in their homes, at clinics and in hospitals.

The Municipal Health Department reports that 20,801 women were cared for at the Public Healthcare facilities in Natal. Based on this number, a sample size (n) was established.

Despite previous pilot study was also conducted with a sample size calculation (n) considering a prevalence (p) of approximately $40 \%$ (sample size based on previous studies), value of normal distribution $=1.96$, (q) $=1-4$, and standard error $2.5 \%$. Thus, the value obtained was 354.04 . It was rounded to 370 , to account for eventual dropouts. The randomization occurred as follows: the patients received a sequential number and only those who randomly received odd numbers were selected for study. Sexual dysfunction frequency observed in a pilot study was also considered when determining sample size. The sample was stratified by region as follows; North - 2271 medical appointments with a stratified sample of 43 women, South - 8602 appointments with a sample of 158 women, East 5528 appointments with 102 women and West - 3579 appointments with a sample of 63 women.

All participants provided informed consent, and the study was approved by the Research Ethics Committee of the Federal University of Rio Grande do Norte, in Natal, Brazil.

Inclusion criteria were healthy women, between 40 and 65 years of age, with at least 11 years of formal education and not using hormonal therapy replacement. Explicit refusal or inability to participate, as well as any other factors that prevented the interview, were considered exclusion criteria. Women with cognitive and/or neurological diseases and those who used psychiatric drugs (antidepressants, anxiolytics and neuroleptics) that could interfere in sexuality were also excluded.

Study objectives, responsibilities and procedures were explained and eligible women awaiting medical care were randomly and individually invited to participate in the study and asked to sign an informed consent form (ICF).

Initially, we applied the specific questionnaire regarding sociodemographic, clinical and behavioral characteristics. These included age, race, marital status, education, income, body mass index, smoking status, menopause and hysterectomy. Menopause was diagnosed based on clinical data (amenorrhea for at least 12 months), high gonadotrophin (FSH> $35 \mathrm{mIU} / \mathrm{mL}$ ) and low estrogen levels $(<20 \mathrm{ng} / \mathrm{dL})$.

The short form of the International Physical Activity Questionnaire (IPAQ) was used to determine physical activity levels of the women under study. This instrument estimates weekly time engaged in different types and intensity of physical activity (work related, housework, transportation and leisure). Physical activity level was classified considering frequency, duration and intensity of the activities performed a week prior to the interview ${ }^{23}$. The study used three categories to classify physical activity levels: very active, moderately active and sedentary. Very active women engage in physical activities of moderate to strong intensity at a frequency of 5 times per week for a time greater than or equal to 30 minutes; moderately active women perform moderate to vigorous physical activities at least three times a week, for 30 minutes or more; and sedentary individuals are those who did not engage in any physical activity for more than 10 continuous minutes. Sexual function was evaluated by the Female Sexual Function Index (FSFI), given its widespread use in the female population ${ }^{24}$. The FSFI was translated and validated for use in Portuguese and consists of a brief self- 
report that assesses the key dimensions of sexual function in women during the previous four weeks ${ }^{25}$. It contains 19 questions with six sexual response domains: desire, arousal, lubrication, orgasm, satisfaction and pain. Individual scores are obtained by summing the items of each domain (single score), which are multiplied by a factor of this domain to provide the weighted score. The higher the score, the better the sexual function within each domain. The final score (minimum 2 and maximum 36) is obtained by summing the weighted scores for each domain, with scores less than or equal to 26.55 points considered sexual dysfunction ${ }^{24}$.

Initially, exploratory data analysis was conducted to calculate the relative frequencies of sociodemographic, behavioral, and clinical variables with physical activity levels (IPAQ). The chi-square test was then applied in order to verify possible associations between physical activity level (IPAQ) and sexual function (FSFI). The variable response was the presence or not of sexual dysfunction, that is, an FSFI score less than or equal to 26.55.

Analysis of variance (ANOVA) was used to identify significant differences between the intensity of FSFI domains, followed by Tukey's multiple comparisons test to establish whether means differ between levels of physical activity. A significance level of 5\% was set for all tests, and Minitab 16 statistical software (Minitab incorporation 2012) was used to analyze the data.

\section{Results}

The average age of the women studied $(\mathrm{N}=370)$ was 49.8 $( \pm 8.1)$ years, $30.3 \%$ aged $40-45$ years, $41.3 \%$ between 46 and 55 years and $28.4 \%$ between 56 and 65 years. The majority exhibited Caucasian traits (72.7\%), were married (61.6\%), with secondary education (47.8\%), body mass index classified as normal (40.3\%) and nonsmokers (93.5\%). It was observed that $45.5 \%$ of the women were postmenopausal and $17 \%$ had undergone hysterectomy. With respect to classification of physical activity levels, 132 (35.7\%) were considered active, 129 (34.9\%) moderately active and 109 (29.4\%) sedentary (Table 1).

Table 2 shows a significant association $(\mathrm{p}=0.002)$ between physical activity levels and the presence or absence of sexual dysfunction. Of the 370 women studied, 243 (67\%) had sexual dysfunction (FSFI $\leq 26.55)$. Sedentary individuals had a higher prevalence $(78.9 \%)$ of sexual dysfunction when compared to active (57.6\%) and moderately active women (66.7\%).

Analysis of variance detected significant differences $(p<0.05)$ in the average domains of sexual function and total FSFI score between levels of physical activity. Phys- ically active females obtained higher scores in all FSFI domains (desire, arousal, lubrication, orgasm, satisfaction and pain), compared to their moderately active and sedentary counterparts. Sedentary women showed lower scores in all domains. Active subjects differed from sedentary individuals in all sexual function domains (Table 3 ).

Considering total FSFI score, the average found in all groups (active, moderately active and sedentary) was lower than 26.55, characterizing sexual dysfunction in all groups. However, active women had the highest total score (20.9), that is, better sexual function when compared to moderately active (18.8) and sedentary (15.6) subjects (Table 3 ).

The results of logistic regression indicated a significant association between sexual dysfunction and physical activity level, age, educational level and menopausal status. Sedentary women were 2.6 (95\% CI:1.4-4.8, p = 0.002 ) times more likely to have sexual dysfunction than active ones. The likelihood of sexual dysfunction in women aged 56-65 years was 2.6 (95\% CI:1.1-6.4, $\mathrm{p}=0.036$ ) times higher than in younger females. The chance of sexual dysfunction in women with higher education levels (secondary and university) was 50\% lower than those with elementary education. It was also found that postmenopausal women were $2.1(95 \% \mathrm{CI}: 1.1-4.1, \mathrm{p}=0.028)$ times more likely to have sexual dysfunction than premenopausal women.

\section{Discussion}

Despite the importance of sexuality and physical activity to the women's quality of life and health, studies addressing the relationship between physical activity and sexual function in middle-aged women remain scarce.

In this study, risk of sexual dysfunction $(\mathrm{FSFI} \leq 26.55)$ was recorded in 243 (67\%) of the 370 women. This risk was strongly associated with sedentary lifestyle. Inactive women exhibited higher prevalence (78.9\%) of sexual dysfunction when compared to their active counterparts (57.6\%). Thus, an inverse relationship was found between both variables, where greater levels of physical activity were associated to lower prevalence of sexual dysfunction. In our study, menopausal women displayed a 2.1-fold higher risk of sexual dysfunction. Other studies show that the dysfunction rate can range from 51 to $75 \%$ in postmenopausal women ${ }^{17,26,27}$. An important study conducted in 11 South American countries using the FSFI, found $56.8 \%$ of sexual dysfunction in women aged $40-59$ years [3]. In a prospective observational study, Dennersteinet al. ${ }^{28}$ reported that female sexual function declines with the natural menopausal transition. 
TABLE 1 Sociodemographic, behavioral and clinical characteristics of the studied population ( $N=370)$

Variables

\begin{tabular}{|l|l|l|l|l|}
\multicolumn{2}{|l|}{ Physical activity levels (IPAQ) } & \\
\hline Active & Moderately active & Sedentary & Total \\
$\mathrm{N} \quad(\%)$ & $\mathrm{N} \quad(\%)$ & $\mathrm{N} \quad(\%)$ & $\mathrm{N} \quad(\%)$
\end{tabular}

\section{Age group}

$40-45$

$46-55$

$56-65$

\begin{tabular}{|l|l|}
\hline 44 & 39.3 \\
\hline 34 & 32.4 \\
\hline 54 & 35.3 \\
\hline
\end{tabular}

39
40
50

\begin{tabular}{|l|l|}
\hline 34.8 & 29 \\
\hline 38.1 & 31 \\
\hline 32.7 & 49 \\
\hline
\end{tabular}

\begin{tabular}{|l|l|l|}
\hline 25.9 & 112 & 30.3 \\
\hline 29.5 & 153 & 41.3 \\
\hline 32.0 & 105 & 28.4 \\
\hline
\end{tabular}

Race

Caucasian

Non- Caucasian

\begin{tabular}{|l|l|l|l|l|l|l|l|}
\hline 102 & 37.9 & 96 & 35.7 & 71 & 26.4 & 269 & 72.7 \\
\hline 30 & 29.7 & 33 & 32.7 & 38 & 37.6 & 101 & 27.3 \\
\hline
\end{tabular}

Marital Status

\begin{tabular}{l|l|l|l|l|l|l|l|l}
\hline Married & 87 & 38.2 & 79 & 34.7 & 62 & 27.1 & 228 & 61.6 \\
\hline Divorced/Separated & 23 & 28.4 & 29 & 35.8 & 29 & 35.8 & 81 & 21.9 \\
\hline Single & 22 & 36.1 & 21 & 34.4 & 18 & 29.5 & 61 & 16.5 \\
\hline
\end{tabular}

\section{Education}

\begin{tabular}{l|l|l|l|l|l|l|l|l}
\hline Elementary & 28 & 25.7 & 41 & 37.6 & 40 & 36.7 & 109 & 29.5 \\
\hline Secondary & 67 & 37.9 & 60 & 33.9 & 50 & 28.3 & 117 & 47.8 \\
\hline University & 37 & 44.1 & 28 & 33.3 & 19 & 22.6 & 84 & 22.7
\end{tabular}

\section{Body Mass Index}

\begin{tabular}{l|l|l|l|l|l|l|l|l}
\hline Normal weight & 57 & 37.5 & 55 & 36.2 & 40 & 26.3 & 149 & 40.3 \\
\hline Overweight & 54 & 38.0 & 48 & 33.8 & 40 & 28.2 & 142 & 39.1 \\
\hline Obese & 21 & 26.6 & 26 & 34.2 & 29 & 38.2 & 76 & 20.6 \\
\hline
\end{tabular}

\section{Smoking}

\begin{tabular}{l|l|l|l|l|l|l|l|l}
\hline Positive & 5 & 20.8 & 11 & 45.8 & 8 & 33.3 & 24 & 6.5 \\
\hline Negative & 127 & 36.7 & 118 & 34.1 & 101 & 29.2 & 346 & 93.5
\end{tabular}

Menopause

\begin{tabular}{l|l|l|l|l|l|l|l|l}
\hline Positive & 55 & 32.7 & 64 & 38.1 & 49 & 29.2 & 168 & 45.5 \\
\hline Negative & 77 & 38.1 & 65 & 32.2 & 60 & 29.7 & 202 & 54.5 \\
\hline
\end{tabular}

\section{Hysterectomy}

\begin{tabular}{l|l|l|l|l|l|l|l|l}
\hline Positive & 18 & 28.6 & 27 & 42.9 & 18 & 28.6 & 63 & 17.0 \\
\hline Negative & 114 & 37.1 & 102 & 33.2 & 91 & 29.6 & 307 & 83.0 \\
\hline
\end{tabular}

\section{TABLE 2 Physical activity levels (IPAQ) and sexual function (FSFI) of the subjects ( $N=370)$}

Physical activity levels (IPAQ)

\begin{tabular}{l}
\hline \\
\hline Active \\
\hline Moderately active \\
\hline Sedentary \\
\hline Total
\end{tabular}

\begin{tabular}{|l}
\hline $\begin{array}{l}\text { Sexual dysfunction } \\
(\mathrm{FSFI} \leq 26.55)\end{array}$ \\
\hline Positive \\
\hline $\mathrm{N}(\%)$ \\
\hline $76(57.6)$ \\
\hline $86(66.7)$ \\
\hline $86(78.9)$ \\
\hline $243(67.0)$ \\
\hline
\end{tabular}

\begin{tabular}{|c|c|}
\hline & Total \\
\hline \multicolumn{2}{|l|}{ Negative } \\
\hline N (\%) & $\mathrm{N}(\%)$ \\
\hline $56(42.4)$ & $132(35.7)$ \\
\hline $43(33.3)$ & $129(34.9)$ \\
\hline $23(21.1)$ & $109(29.4)$ \\
\hline $122(33.0)$ & $370(100.0)$ \\
\hline
\end{tabular}


TABLE 3 Physical activity levels (IPAQ) associated to FSFI domains

\begin{tabular}{l|l|l|l|l} 
& \multicolumn{3}{|c|}{ Physical activity levels (IPAQ) } \\
\hline \multirow{2}{*}{ FSFI Domains } & Mctive & $\begin{array}{l}\text { Moderately } \\
\text { Active } \\
\text { Mean }(S D)\end{array}$ & $\begin{array}{l}\text { Sedentary } \\
\text { Mean }(S D)\end{array}$ & P-value* \\
\hline Desire & $3.4^{\mathrm{a}}(1.4)$ & $3.2^{\mathrm{ab}}(1.2)$ & $3.0^{\mathrm{b}}(1.3)$ & 0.047 \\
\hline Arousal & $3.1^{\mathrm{a}}(2.0)$ & $2.8^{\mathrm{a}}(2.0)$ & $2.1^{\mathrm{b}}(1.9)$ & 0.001 \\
\hline Lubrication & $3.4^{\mathrm{a}}(2.2)$ & $3.2^{\mathrm{ab}}(2.3)$ & $2.6^{\mathrm{b}}(2.3)$ & 0.012 \\
\hline Orgasm & $3.5^{\mathrm{a}}(2.2)$ & $3.2^{\mathrm{a}}(2.2)$ & $2.5^{\mathrm{b}}(2.2)$ & 0.002 \\
\hline Satisfaction & $4.0^{\mathrm{a}}(2.0)$ & $3.4^{\mathrm{ab}}(2.1)$ & $2.9^{\mathrm{b}}\left(2.2^{2}\right)$ & 0.001 \\
\hline Pain & $3.6^{\mathrm{a}}(2.4)$ & $3.1^{\mathrm{ab}}(2.3)$ & $2.6^{\mathrm{b}}(2.4)$ & 0.004 \\
\hline Total FSFI & $20.9^{\mathrm{a}}(11.2)$ & $18.8^{\mathrm{ab}}(11.1)$ & $15.6^{\mathrm{b}}(11.0)$ & 0.001 \\
\hline
\end{tabular}

*ANOVA Test; $5 \%$ significance level. SD= standard deviation. Means that do not share a letter are significantly different.

Dabrowska et al. ${ }^{12}$ studied 336 Polish women, aged 45-55 years and also found an association between higher levels of general physical activity and better sexual function. Low physical activity levels related to work, transportation, housework and leisure were correlated with reduced sexual function. As in our study, results were obtained from FSFI and IPAQ scores.

Both studies add to the understanding of the association between physical activity level and sexual function. Both studies used widely applied scales, reducing the likelihood of systematic errors. The results of these studies have valuable implications for all health care professionals working with women in the perimenopausal and menopausal stages.

Another study was conducted in California with members of a fitness program, aged 50 years and older. Results indicated a high level of sexual activity and satisfaction in both older men and women. Sexual satisfaction seemed to correlate with fitness level, both mutually supportive elements of successful aging ${ }^{29}$.

The literature also cites the positive effects of regular physical activity on menopausal women, in addition to an indirect effect on sexuality through the production of hormones. It is thought that physical activity increases the synaptic transmission of monoamines ${ }^{30}$, which supposedly functions in the same manner as antidepressants ${ }^{5}$. Studies also show that physical activity causes the release of endogenous opioids, which have a calming effect and improve mood post exercise ${ }^{7}$.

Randomized trials in middle-aged women also demonstrated that aerobic exercise can lead to significant improvement in a number of menopause symptoms (e.g., mood and insomnia), physical and psychological health and quality of life, possibly reflected in enhanced sexual function ${ }^{31}$.

Our results show that active middle-aged women obtained the highest means and total scores on all FSFI domains (desire, arousal, lubrication, orgasm, satisfaction, and pain), compared to moderately active and sedentary subjects. Li et al. ${ }^{16}$ assessed perimenopausal women and observed that moderately active or very active women demonstrated less sexual dysfunction, especially vaginal dryness and decreased sexual desire, than physically inactive women. The present study shows a significant inverse correlation between menopausal symptoms and sexual function, and that physical activity reduces the symptoms of menopause, as documented in several other investigations ${ }^{18,19,32}$. In other studies of middle-aged women, physical exercise not only reduced the intensity of menopausal symptoms, but was also effective in improving sexuality during middle age ${ }^{15,29,33}$.

Understanding the effects of physical activity on sexuality can potentially have a positive influence on the clinical practice of physicians. Doctors rarely recommend that their patients exercise more, despite the documented advantages of systematic physical exercise. This could possibly promote a more satisfactory quality of life and prevent sexual dysfunction.

\section{Conclusions}

Physical activity appears to have a positive influence on sexual function in middle-aged women.

In spite of these interesting results, the present study should be interpreted with caution and the following limitations must be considered: the degree of sexual dysfunction was self-reported; specific causes of sexual dysfunction were not diagnosed; and factors such as pelvic floor disorders that could influence the reporting of sexual function were not considered. Consequently, the study does not firmly establish whether the sexual dysfunction of the study participants, as measured by FSFI, is influenced by physical activity or other variables.

Alternative study designs (longitudinal or qualitative), with assessments before and after physical activity interventions, could offer new insights into the relation- 
ship between physical activity levels and sexual function in middle-aged women.

\section{Resumo}

Atividade física e função sexual em mulheres de meia idade.

Objetivo: Avaliar uma possível relação existente entre a prática de atividade física e a função sexual em mulheres de meia idade.

Métodos: Estudo de corte transversal com 370 mulheres entre 40 e 65 anos, atendidas em unidades públicas de saúde em uma cidade brasileira de médio porte. Foi utilizado questionário para avaliar características sociodemográficas, clinicas e comportamentais, o IPAQ (International Physical Activity Questionnaire) para avaliar nível de atividade física e o FSFI (Female Sexual Function Index) para avaliar sexualidade.

Resultados: A média de idade das mulheres estudadas foi de 49.8 anos ( \pm 8.1 ), 67\% delas apresentaram algum grau de disfunção sexual (FSFI $\leq 26.55)$. Mulheres sedentárias apresentaram maior prevalência de disfunção sexual (78.9\%) quando comparadas as mulheres ativas (57.6\%) e moderadamente ativas $(66.7 \%)(\mathrm{p}=0.002)$. Mulheres fisicamente ativas obtiveram maiores escores do FSFI total (20.9) e em todos os domínios (desejo, excitação, lubrificação, orgasmo, satisfação e dor) quando comparadas as moderadamente ativas com escore total de 18,8 e sedentárias de 15,6 ( $\mathrm{p}<0.05)$, indicando melhor função sexual das fisicamente ativas quando comparadas as sedentárias.

Conclusão: A atividade física parece influenciar favoravelmente a função sexual de mulheres de meia idade.

Unitermos: atividade física, sexualidade, mulheres de meia-idade, menopausa.

\section{RefERences}

1. Leitão MB, Lazzoli JK, Oliveira MAB, Nóbrega ACL, Silveira GG, Carvalho $\mathrm{T}$, et al. Posicionamento Oficial da Sociedade Brasileira de Medicina do Esporte: Atividade Física e Saúde na Mulher. Rev Bras Med Esporte. 2000;6(6):215-20.

2. Lavie CJ, Thomas RJ, Squires RW, Allison TG, Milani RV. Exercise training and cardiac rehabilitation in primary and secondary prevention of coronary heart disease. Mayo Clin Proc. 2009;84(4):373-83.

3. Lee IM, Shiroma EJ, Lobelo F, Puska P, Blair SN, Katzmarzyk PT.Effect of physical inactivity on major non-communicable diseases worldwide: an analysis of burden of disease and life expectancy. Lancet. 2012;380(9838):219-29.

4. Winzer BM, Whiteman DC, Reeves MM, Paratz JD. Physical activity and cancer prevention: a systematic review of clinical trials. Cancer Causes Control. 2011;22(6):811-26.

5. Miles L. Physical activity and health. Nutr Bull. 2007;32(4):314-63.

6. Nelson ME, Rejeski WJ, Blair SN,Duncan PW, Judge JO, King AC, et al. Physical Activity and public health in older adults: recommendation from the American Heart from the American College of Sport Medicine and the American Heart Association. Circulation. 2007;116(9):1094-195.

7. Dinas PC, Koutedakis Y, Flouris AD. Effects of exercise and physical activity on depression.Ir J Med Sci. 2011;180(2):319-25.
8. Schulz KH, Meyer A, Langguth N. Exercise and psychological well-being. Bundesgesundheitsblatt Gesundheitsforschung Gesundheitsschutz. 2012;55(1):55-65

9. Salmon P. Effects of physical exercise on anxiety, depression, and sensitivity to stress: a unifying theory. Clin Psychol Rev. 2001;21(1):33-61.

10. Peluso MAM, Andrade HSG. Physical activity and mental health: the association between exercise and mood. Clinics. 2005;60(1):61-70.

11. Woloski-Wruble AC, Oliel Y, Leefsma M, Hochner-Celnikier D. Sexual activities, sexual and life satisfaction, and successful aging in women. J Sex Med 2010;7(7):2401-10

12. Dabrowska J, Drosdzol A, Skrzypulec V, Plinta R. Physical activity and sexuality in perimenopausal women. Eur J Contracept Reproduct Health Care. 2010;15(6):423-32.

13. Elavsky S, McAuley E, Moti RW, Konopack JF, Marquez DX, Hu L. Longitudinal examination of the exercise and self-esteem model in middleaged women.J Sport Exerc Psychol. 2010;32(6):862-80.

14. Ferreira M, Matsudo S, Matsudo V, Braggion G. Efeitos de um programa de orientação de atividade física e nutricional sobre o nível de atividade física de mulheres fisicamente ativas de 50 a 72 anos de idade. Rev Bras Med Esporte. 2005,11(1):172-6.

15. Skrzypulec V, Dabrowska J, Drosdzol A. The influence of physical activity level on climacteric symptoms in menopausal women. Climacteric 2010; 13(4):355-61.

16. Li S, Holm K, Gulanick M, Lanuza D, Penckofer S. The Relationship between physical activity and perimenopause. Health Care Women Int1999; 20(2):163-78.

17. Llaneza P, Fernández-I narrea JM, Arnott B, García-Portilla MP, Chedraui P, Pérez-López FR. Sexual function assessment in postmenopausal women with the 14-item changes in sexual functioning questionnaire. J Sex Med. 2011;8(8):2144-51

18. Chedraui P, Pérez-López FR, Mezones-Holguin E, San Miguel G, Avila C. Assessing predictors of sexual function in mid-aged sexually active women. Maturitas. 2011;68(4):387-90.

19. Chedraui P, Pérez-Lopez FR, Sánchez H, Aguirre W, Martínez N, Miranda $\mathrm{O}$, et al. Assessment of sexual function of mid-aged Ecuadorian women with the 6-item Female Sexual Function Index. Maturitas.2012;71(4):407-12.

20. Bernis C, Reher DS. Environmental contexts of menopause in Spain: comparative results from recent research. Menopause. 2007;14(4):777-87.

21. Lindh-Astrand L, Nedstrand E, Wyon Y, Hammar M. Vasomotor symptoms and quality of life in previously sedentary postmenopausal women randomised to physical activity or estrogen therapy. Maturitas. 2004;48(2):97-105.

22. Sonstroem RJ, Potts SA. Life adjustment correlates of physical self-concepts. Med Sci Sports Exerc. 1996;28(5):619-25.

23. Matsudo S, Araújo T, Matsudo V, Andrade D, Andrade E, Oliveira LC, et al.International Physical Activity Questionnaire (IPAQ): validity and reproducibility in Brazil. Rev Bras Ativ Fís Saúde. 2001;6(1):5-18.

24. Rosen R, Brown C, Heiman J, Leiblum S, Meston C, Shabsigh R, et al. The Female Sexual Function Index (FSFI): a multidimensional self-report instrument for the assessment of female sexual function. J Sex Marital Ther. 2000; 26(2):191-208.

25. Thiel RRC, Dambros M, Palma PCR, Thiel M, Riccetto CLZ, Ramos MF.Translation into Portuguese, cross-national adaptation and validation of the Female Sexual Function Index. Rev Bras Ginecol Obstet. 2008;30(10):504-10.

26. Valadares AL, Pinto-Neto AM, Osis MJ, Conde DM, Sousa MH, Costa-Paiva L.Sexuality in Brazilian women aged 40 to 65 years with 11 years or more of formal education: associated factors. Menopause. 2008;. 15(2):264-269.

27. Chedraui P, Pérez-López FR, San Miguel G, Avila C.Assessment of sexuality among middle aged women using the Female Sexual Function Index. Climacteric. 2009;12(3):213-21.

28. Dennerstein L, Randolph J, Taffe J, Dudley E, Burger H. Hormones, mood, sexuality, and the menopausal transition. FertilSteril 2002; 77(4):42-8

29. Bortz WM, Wallace DH. Physical fitness, aging, and sexuality. West J Med. 1999;170(3):167-9

30. Mead GE, Morley W, Campbell P, Greig CA, McMurdo M, Lawlor DA. Exercise for depression. Cochrane Database Syst Rev. 2009;8:CD004366.

31. Daley AJ, Stokes-Lampard HJ, Macarthur C.Exercise to reduce vasomotor and other menopausal symptoms: a review. Maturitas. 2009;63(3):176-80 doi: 10.1016/j.maturitas.2009.02.004

32. Canário AC, Cabral PU, Spyrides MH, Giraldo PC, Eleutério J Jr, Gonçalves AK. The impact of physical activity on menopausal symptoms in middleaged women.Int J Gynaecol Obstet. 2012;118(1):34-6.

33. Cabral PU, Canário AC, Spyrides MH, Uchôa SA, Eleutério J Jr, Amaral RL, et al.Influence of menopausal symptoms on sexual function in middle-aged women. Rev Bras Ginecol Obstet. 2012;34(7):329-34. 